\title{
Investigación arqueométrica de los ladrillos de las antiguas murallas defensivas de la ciudad de Pavía (norte de Italia)
}

\section{Archaeometric study of bricks from the ancient defence walls around the town of Pavia in northern Italy}

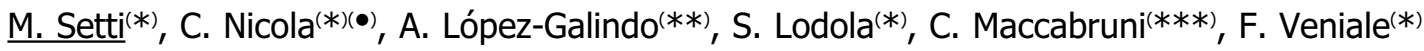

Recepción/Received: 7-XII-05

Aceptación/Accepted: 4-V-06

\section{RESUMEN}

Se investigan ladrillos recogidos en las murallas defensivas de la histórica ciudad de Pavía (norte de Italia), que fueron construidas en tiempos romanos (no establecidos) y "españoles" (siglos XVI y XVII).

En base al color, composición química tanto total como puntual, asociaciones mineralógicas y características texturales, se concluye que se utilizó una materia prima similar en ambas épocas, con algunas particularidades: granulometría más fina en los romanos, adición de carbonato molido y chamota en los "españoles". Por su parte, la porosidad es mayor en los ladrillos "españoles". El amplio rango de temperaturas de cocción observado para estos últimos debe estar relacionado con los distintos usos para los cuales fueron destinados. La presencia esporádica de maghemita se discute, además, en función del tipo de atmósfera imperante en el horno de cocción. El color de los ladrillos "españoles" es más claro, como corresponde a su mayor contenido en carbonatos y menor temperatura de cocción. Estas características ejercen una notable influencia en la resistencia a la meteorización de los distintos tipos de ladrillos y deben, ser tenidas en cuenta a la hora de elaborar posibles planes de restauración.

Palabras clave: ladrillos, murallas romanas españolas, Pavía, color, composición química.

\section{SUMMARY}

A study was conducted on bricks sampled from the defence walls around the historic town of Pavia (northern Italy) erected during Roman (uncertain) and "Spanish" (sixteenth-seventeenth centuries) times.

An analysis of colour, macro- and micro-chemical composition, mineralogical clusters and structural-textural features showed that similar raw materials were used in the manufacture of these bricks, although certain variations were identified: particle size is finer in Roman bricks, while the "Spanish" version contains ground carbonate and "chamotte" additives. The "Spanish" bricks, fired at lower temperatures, are more porous. The wide range of firing temperatures used to make "Spanish" bricks was very likely related to the intended use. The sporadic presence of maghemite is discussed in the context of the atmosphere prevailing in the kilns. The "Spanish" bricks are lighter in colour as a result of their carbonate content and lower firing temperature. These characteristics, which affect the weather resistance of the different types of brick, should be taken into account in restoration work.

Keywords: bricks, Roman Spanish walls, Pavia, colour, chemical composition.

\footnotetext{
(*) Dipartimento di Scienze della Terra, University of Pavia (Italia).

(**) Instituto Andaluz de Ciencias de la Tierra - CSIC, University of Granada (España).

$(* * *)$ Dipartimento di Scienze dell'Antichità, University of Pavia (Italia).

(•) Present address: Dipartimento scienze della Terra, University of Milan (Italia).
} 


\section{INTRODUCCIÓN}

El presente trabajo forma parte de un proyecto que estudia la manufacturación de ladrillería durante distintas épocas (desde romana y medieval hasta el Renacimiento y Barroco) en la zona de la provincia de Pavía, al norte de Italia. Algunas investigaciones previas se han centrado en el enclave arqueológico denominado "Villa Maria" en Lomello, una localidad situada a unos $35 \mathrm{~km}$ al W de Pavía $(1,2,3)$, y a la Torre Cívica de Pavía, que colapsó en $1989(4,5,6)$.

Presentamos aquí los resultados obtenidos durante el estudio de los ladrillos usados durante la construcción de la muralla defensiva de la ciudad de Pavía, tanto en tiempos romanos como "españoles" (ver el apartado "Breve reseña histórica"). Nicola (7) realizó un estudio preliminar.

Los objetivos de esta investigación han sido: (i) reconocer la materia prima usada durante la fabricación de los ladrillos; (ii) determinar el proceso de ajuste de composición del material original, así como establecer las condiciones de cocción; (iii) observar la influencia de la textura y estructura original en la durabilidad de los ladrillos, y en su deterioro, debido a la meteorización; y (iv) proponer intervenciones para una correcta conservación y restauración de los muros.

Se están llevando a cabo, además, investigaciones adicionales sobre los tipos de mortero empleados en la construcción de las murallas, así como en bastiones de gran tamaño, llamados "Rotonda", construidos en Pavía durante la ocupación española (siglos XVI y XVII).

\section{BREVE RESEÑA HISTÓRICA}

La ciudad de Pavía se localiza en la llanura del río Po, al norte de Italia, y más concretamente en la ribera de su afluente Ticino, a unos $6 \mathrm{~km}$ de la confluencia de ambos ríos.

Según registros históricos (8), los primeros asentamientos en el lugar pueden ser atribuidos al pueblo lígure; más tarde (50-30 a.C.) se convirtió en cuartel militar romano y en un "Municipium" llamado Ticinum.

La ciudad se desarrolló principalmente en la ribera izquierda del río Ticino, conservando la planta del campamento romano; de hecho, las calles principales actuales corresponden a las originales y perpendiculares "Cardo" (N-S) y "Decumanus" (E-W). En la ladera derecha del río creció igualmente un pequeño enclave.

Respecto a sus defensas [Figura 1, desde (9); ver también (10 y 11)], están datados inciertamente los muros romanos, que además fueron modificados al final del

\section{INTRODUCTION}

The present study forms a part of a broader project on historical brick structures erected at different times (from Roman to Medieval, Renaissance and Baroque) in the territory of the northern Italian province of Pavia. Earlier research focused on the "Villa Maria" archaeological site at Lomello, a village located about $35 \mathrm{~km}$ west of Pavia (1, 2, 3), and the Civic Tower of Pavia that collapsed in $1989(4,5,6)$.

The results reported here are for the bricks used to build the defence walls around the town during Roman and "Spanish" times (see the "Historical background" section below); preliminary research was conducted by Nicola (7).

The study aimed to: (i) identify the raw materials used to make the bricks; (ii) determine the procedures used to adjust the composition of the raw materials and firing conditions; (iii) establish the impact of structural-textural features on durability and deterioration due to weathering; and (iv) consider the consequences for conservation and restoration.

Further research is in progress on both the brick and the mortar in the impressive bastions (known as "rotonda") built in Pavia during the "Spanish" occupation (sixteenthseventeenth centuries).

\section{HISTORICAL BACKGROUND}

Pavia is located in the Po River valley in northern Italy, and more precisely on the banks of the Ticino River about $6 \mathrm{~km}$ upstream of its convergence with the Po.

According to historical records (8), the first settlement, attributed to the Ligurians, later became a Roman military post and "municipium" called Ticinum.

Pavia grew primarily along the left bank of the Ticino River, adopting the layout of the former Roman post; even today, the hub of the town's planning scheme consists in two perpendicular main streets, reminiscent of the typical Roman "Cardo" (N-S) and "Decumanus" $(E-W)$. A small quarter later grew up on the right bank.

The layout of the Roman walls [Figure 1 in (9); see also $(10,11)]$, which have not been precisely dated, was changed towards the end of Longobard's reign (late 
dominio longobardo (finales del siglo VIII). En esa época cambió hacia "Papia" el nombre de la ciudad (de donde proviene su actual denominación), siendo además capital del "Regnum Italicum". Con posterioridad, el emperador Lotario (Acta fechada en 825 d.C.) estableció en la misma un "Studium", considerado como germen de su Universidad (Alma Ticinensis Universitas), que fue refundada en 1361, tras un largo declive político y económico, por Galeazzo Visconti II, duque de Milán, regidor de los destinos de la región en dicha época.

Los muros medievales datan del siglo $X$, y su construcción se debe al obispo Juan III. La edificación de los llamados muros y bastiones "españoles" comenzó en el año 1547 y duró hasta el siglo XVII, i.e., durante la ocupación que siguió a la "Batalla de Pavía" (24 de febrero de 1525), en la cual el ejército imperial de Carlos $V$ venció al rey de Francia, Francisco I. En dicho evento murió el famoso Señor de Lapalisse, general del ejército francés.

\section{MATERIALES}

El muestreo de los materiales investigados se ha efectuado en diferentes lugares (Figura 1); las muestras escogidas (15 ladrillos de época romana y 20 "españoles") son suficientemente representativas de los distintos tipos de manufacturación existentes: estructura frontal y restos apilados del antiguo Puente Cubierto (época romana), destruido tras los bombardeos de la II Guerra Mundial (1944), y bastiones de San Epifanio y puerta Calcinara (periodo "español"). Unas pocas muestras se tomaron, además, en los restos de la Torre de la Gran Cadena, construida a comienzos del siglo XV, cuando la ciudad estaba bajo dominio del duque Felipe María Visconti, con el objetivo de mantener alejados del puerto fluvial a los barcos enemigos (11 bis).

Varias muestras presentan bordes descoloridos debido a la meteorización, siendo el espesor de los mismos variable (sobre $5 \mathrm{~mm}$ o menos); hemos estudiado de forma separada dichos bordes y los núcleos inalterados de los ladrillos.

\section{MÉTODOS}

Las distintas técnicas analíticas empleadas habitualmente en el estudio de cerámicas antiguas se recogen en (12); ver también (13) y (14) para los métodos usados en materiales arcillosos.

Se han aplicado observaciones visuales al color, granulometría y relación matriz/degrasante, siguiendo los esquemas sugeridos por (15) y (16); el color se ha clasificado según (17). Estas características representan "huellas digitales" de la formulación del adobe y su moldeo, así como de las condiciones de uso del horno de cocción. eighth century), when the town was re-named Papia (from which the present Pavia derives). At the time, the town was the capital of the "Regnum Italicum" where the emperor Lotarius later established a "Studium" (order dated 825 a.D.), regarded to be the root from which the Alma Ticinensis Universitas would later stem. This university was re-founded in 1361 after a long period of political and economic decline by the contemporary ruler Galeazzo Visconti II, Duke of Milan.

The town owes it tenth century Medieval walls to Bishop Johannes III. Construction of the so-called "Spanish" walls and bastions began in 1547 and continued through the seventeenth century, i.e., during the "Spanish" occupation that followed the Battle of Pavia (24 February 1525), where Charles V's imperial army defeated the forces of the French King Francis I. The famous French general Monsieur de Lapalisse was killed during that battle.

\section{MATERIALS}

The materials studied were sampled at different sites (Figure 1); the specimens selected (15 Roman and 20 "Spanish" bricks) can be regarded to be sufficiently representative of the different types found on the various structures. Specifically, brick was taken from the sides and remains of a pile of the covered Old (Roman) Bridge destroyed during World War II (1944), and from the St Epiphanius bastions and Calcinara Gate in the "Spanish" walls. A further series of samples was taken from the ruins of a tie-bar tower built in the early fifteenth century by Duke Filippo Maria Visconti to defend the river port from enemy ships (11 bis).

The decoloured, weathered rims of varying thickness (around $5 \mathrm{~mm}$ or less) found on several of the samples were studied separately from the unweathered cores.

\section{METHODS}

For a review of analytical techniques used for studying ancient fired clay, see (12), and (13), (14) for a discussion of the analysis of clayey materials.

Visual examinations covered properties such as colour, particle size distribution and the matrix/aggregate ratio, as specified in (15) and (16); colour was classified as described in (17). These "fingerprints" provided insight into how the green brick was worked and moulded, as well as information on kiln firing conditions. 


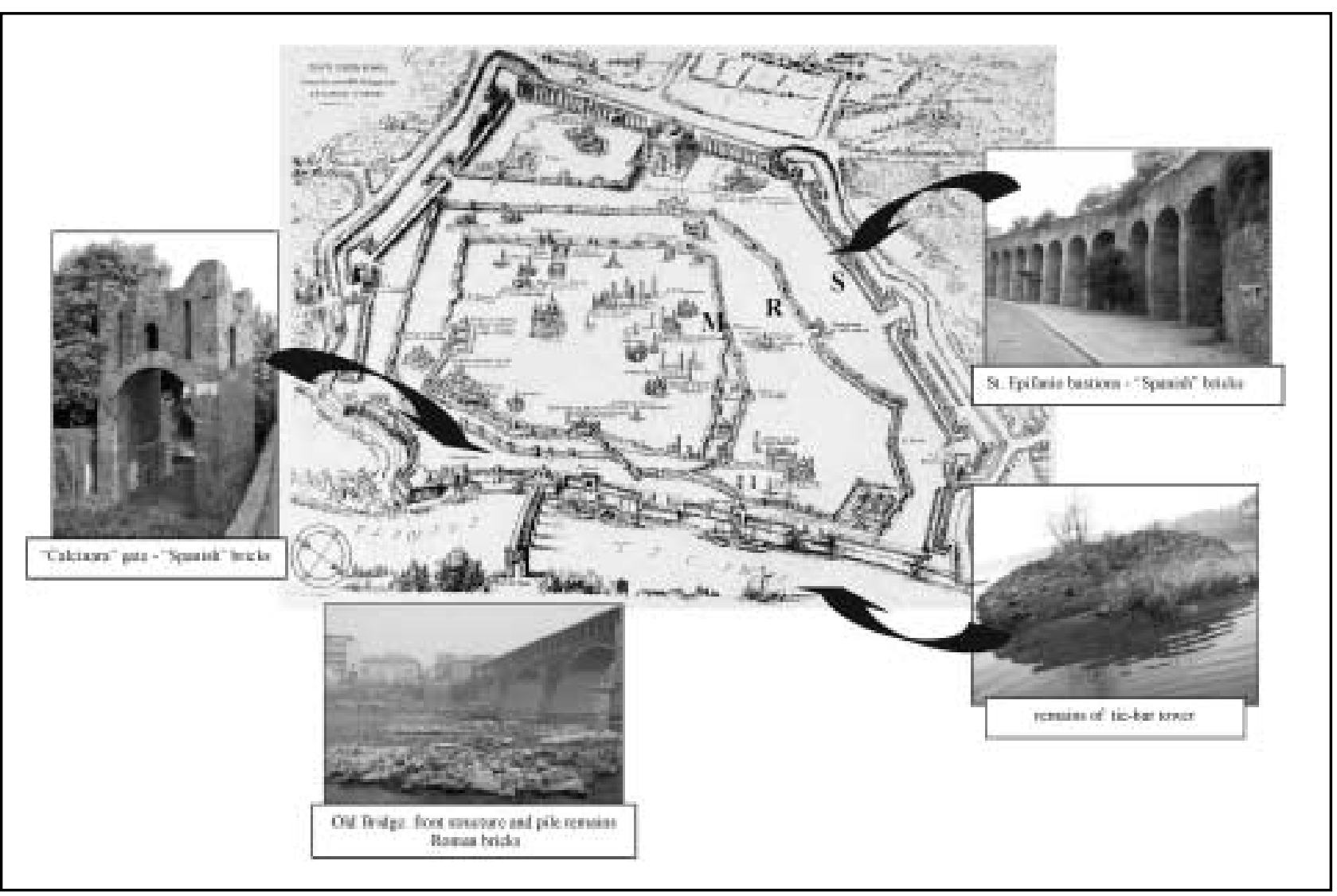

Figura 1. Mapa histórico de la ciudad de Pavía donde se aprecian las murallas construidas en distintas épocas ( $\mathrm{R}=$ Romanas; $\mathrm{M}=$ Medievales; $\mathrm{S}=$ "Españolas") y los sitios de muestreo.

Figure 1. Historical map of Pavia, showing the walls built in different ages $(R=$ Roman; $M=$ Middle Ages, $S=$ "Spanish") and the sampling sites.

El estudio petrográfico se ha efectuado en láminas delgadas mediante microscopía óptica de luz polarizada, que suministra información tanto de la "fábrica" como del color de la matriz, así como de la naturaleza y densidad de los granos del degrasante. Igualmente, permite reconocer fases secundarias y/o de neoformación (18).

La microscopía electrónica de barrido (SEM) ha resultado útil en la observación de las superficies de fractura de las muestras originales, y secciones pulidas de las mismas permitieron evaluar en detalle las modificaciones microestructurales generadas durante el proceso de cocción. Mediante espectrometría de dispersión de energía (EDS) $(19,20)$ se ha controlado el comportamiento químico de las fases originales y neoformadas.

El proceso de análisis de imagen se llevó a cabo en sectores específicos de láminas delgadas, que presentaban rasgos texturales y estructurales peculiares. Gracias a esta técnica hemos podido estudiar la distribución granulométrica y el grado de redondez de los granos del degrasante, así como la forma y tamaño de los poros [ver (21) para una descripción metodológica completa].
Petrographic studies were conducted on thin sections under a polarizing optical microscope to examine matrix structure, texture and colour, as well as the nature and density of the aggregate grains, and identify secondary and/or newly-formed phases (18).

Scanning electron microscopic (SEM) examination of fracture surfaces and polished sections provided detailed information on the microtextural changes taking place during firing. The chemical composition of the initial and newlyformed phases was determined by means of coupled energy dispersive spectroscopic (EDS) analysis (19, 20).

Computer imaging was performed on thin sections for a detailed analysis of specific textural-structural features: particle size distribution, roundness of temper grains, and size and shape of matrix pores; see (21) for a discussion of the methodology involved. 
Mediante difracción de rayos $\mathrm{X}(\mathrm{XRD})$ hemos determinado la composición mineral global, usando muestras de polvo para la muestra total (i) y agregados orientados para la fracción $<2 \mu \mathrm{m}$ (ii), tanto normales como solvatados con etilén-glicol o calentados. Para cuantificar las fases amorfas se siguió el método propuesto por (22).

Finalmente, hemos seleccionado algunas muestras en base a su mineralogía, textura, estructura y color para efectuar un análisis químico de las mismas. El mismo se ha realizado en los laboratorios ACT- LABS (Ancaster, Ontario-Canadá) mediante fluorescencia de rayos $\mathrm{X}$ y plasma por acoplamiento inductivo con espectrómetro de masas (ICP-MS).

\section{RESULTADOS}

La forma de los ladrillos romanos varía de rectangular a cuadrada, y raramente triangulares, mientras que los "españoles" son normalmente rectangulares. En general, los ladrillos rectangulares romanos (así como los de la Torre de la Gran Cadena) tienen un tamaño (28-29x18$20 \mathrm{~cm}$ ) mayor que los "españoles" (22-27x9-14 cm); el espesor es, en todos los casos, de 6,5-8 cm. Hemos encontrado algunos ejemplos de ladrillos más grandes en los ángulos de la construcción. Igualmente existen ladrillos de otras medidas, denominados por los romanos "sesquipedales", que tienen $44,4 \mathrm{~cm}$ de longitud.

El color de los ladrillos "españoles" es ligeramente más claro (naranja rojizo claro: 10 R 6/6 de la carta de Munsell), mientras que los romanos son marrón rojizo claro (10 R 4/6). Otros ladrillos españoles, de tamaño diferente al habitual, exhiben un color rojo oscuro (5R). En la Torre de la Gran Cadena se han encontrado, además, ladrillos con el núcleo bastante oscuro, mientras que el borde es de tonalidades claras.

Las observaciones realizadas con el microscopio óptico ponen de manifiesto una cierta similaritud composicional en los granos del degrasante: cuarzo, feldespato potási$\mathrm{co}$, mica como fases principales $\mathrm{y}$, en cantidades menores, plagioclasas, anfíbol y carbonatos. Los fragmentos líticos consisten en agregados mono y policristalinos de cuarzo y feldespatos. Se han reconocido igualmente fragmentos marrón-rojizos de chamota. Los granos de cuarzo y feldespato presentan, a veces, bordes de reacción. Los cristales de mica que han preservado su hábito original son, en general, ópticamente isótropos. Dispersos en la matriz de algunos ladrillos se distinguen, además, cristales de calcita secundaria.

Aunque predomina una cierta homogeneidad (Figura 2), se pueden establecer diferencias texturales y estructurales con respecto a la granulometría, selección de tamaños
The mineralogical composition was determined by $X$-ray diffraction (XRD) applied to: (i) a random powder specimen for the sample as a whole, and (ii) preferentially oriented specimen for the $<2 \mu \mathrm{m}$ fraction; the latter was scanned both before and after heating and ethylene-glycol solvation. Roughly detections were also concerning the amorphous-vitreous components (22).

Samples were selected for chemical analysis on the basis of their mineralogical composition, structure-texture and body colour. $X$-ray fluorescence and inductively coupled plasma mass spectroscopy (ICP-MS) were performed at ACT-LABS (Ancaster, Ontario, Canada).

\section{RESULTS}

Roman bricks vary in shape from rectangular to square or, rarely, triangular, whereas "Spanish" bricks are primarily rectangular. Generally speaking, Roman bricks (and the bricks from the 15th century tower) are larger $(28-29 / 18-20 \mathrm{~cm})$ than the "Spanish" variety (22-27/9$14 \mathrm{~cm}$ ). All are $6.5-8 \mathrm{~cm}$ thick. The bricks used in corners are sometimes larger and there are typical Roman "sesquipedal" bricks measuring $44.4 \mathrm{~cm}$ long.

"Spanish" bricks are somewhat lighter in hue (medium reddish orange: medium reddish brown: $10 \mathrm{R} 6 / 6$ on the Munsell chart) than the Roman bricks (10 R 4/6). Other "Spanish" bricks differ from the norm both in size and colour (dusky red: 5R range). Finally, some of the bricks from the tie-bar tower have a dark core and lighter colour rim.

Optical microscopic findings revealed compositional similarities in aggregate grains: quartz, $K$-feldspar, mica and, secondarily, plagioclase, amphibole and carbonates. The stone fragments were observed to consist in mono- and polycrystalline quartz and feldspar clusters. Brownish-red "chamotte" fragments were also identified. Some of the quartz and feldspar grains had reaction rims. When preserving their habitus, mica lamellae were found to be mainly isotropic; otherwise, they were exfoliated. Diffuse secondary calcite was observed in several brick matrices.

Despite the overall homogeneity in the samples, the texture-structure (Figure 2) was found to differ in terms of particle size distribution, porosity and matrix/aggregate 
y relación matriz/degrasante. La matriz puede alcanzar hasta el $60-85 \%$ del total, y la porosidad, el 5-15\%. Algunos ladrillos "españoles" contienen granos de degrasante de mayor tamaño, y presentan además una distribución menos homogénea de los mismos, una escasa matriz (40-55\%) y una porosidad más elevada (hasta el $30 \%$ ).

El análisis de imagen (de zonas seleccionadas en las láminas delgadas) se ha centrado en el diámetro medio y grado de redondez de los granos del degrasante, y de la relación degrasante/matriz (Figura 3). La cantidad de degrasante es más alta en los ladrillos "españoles" y en algunas muestras de la Torre de la Gran Cadena. En los ladrillos romanos prevalece un tamaño de grano pequeño y homogéneo, con un grado elevado de redondez. Por el contrario, algunos ladrillos "españoles" contienen granos bastante gruesos y heterogéneos, con bajo grado de redondez, parámetro este último claramente influenciado por la existencia de cristales elongados de mica.

La composición mineral encontrada permite clasificar a los ladrillos estudiados en función de su contenido en fases originales (minerales de la arcilla, micas, cuarzo, feldespatos y anfíboles) y fases neoformadas (gehlenita, diópsido, silicatos cálcicos, hematites y maghemita). La cantidad de materia vítrea es igualmente variable. Se han distinguido los siguientes grupos (Figura 4):

A) Ladrillos tanto romanos como "españoles": ausencia de minerales de la arcilla originales y alto contenido de fases neoformadas, ausencia de gehlenita si la cantidad de cuarzo y feldespatos es elevada; la proporción de material amorfo es bastante alta, aunque en determinados ladrillos romanos de gran tamaño (ángulos y "sesquipedales") es relativamente baja; la hematites está presente como fase accesoria original y también secundaria.

B) Pocas muestras, principalmente ladrillos "españoles": cantidades significativas de mica, caolinita y anfíbol, junto a cantidades menores de fases neoformadas y material amorfo.

Probablemente, la calcita encontrada en los grupos $A$ y $B$ tiene un origen secundario ( $i a$ partir de morteros?), al igual que ocurre con el yeso.

C) Sólo ladrillos "españoles": contenidos elevados de mica, minerales de la arcilla, anfíboles y algo de calcita primaria; fases neoformadas escasas y material amorfo minoritario.

Los ladrillos de la Torra de la Gran Cadena se incluyen en los grupos $A$ y $B$.

La microscopía electrónica de barrido (SEM) efectuada en ladrillos seleccionados ha permitido observar algunos rasgos microtexturales peculiares, tales como el ordenamiento espacial de las partículas de arcilla dentro de la matriz, forma y tamaño de la porosidad secundaria, ratio, with the matrix ranging from 60 to $85 \%$ and porosity from 5 to $15 \%$. Some of the "Spanish" bricks were characterized by a less homogeneous and coarser size aggregate, a sparser matrix (40-55\%) and higher porosity (up to $30 \%$ ).

The computer imaging of thin sections selected on the grounds of optical microscopic findings focused on mean diameter, and roundness of aggregate grains and the aggregate/matrix ratio (Figure 3). The proportion of aggregate was observed to be highest in the "Spanish" bricks and some of the samples taken from the tie-bar tower. A homogeneous fine-grained aggregate prevailed in the Roman bricks; the grains of this temper were also found to be rounder. Some of the "Spanish" bricks had the coarsest, most heterogeneous and least round aggregate grains, although the presence of elongated mica lamellae would affect the readings for the last parameter.

The mineralogical findings were used to group the bricks according to their raw constituents (clay minerals, mica, quartz, feldspar and amphibole) and newly-formed phases (gehlenite, diopside, Ca-Si-silicates, hematite and maghemite). The amount of vitreous matter was found to vary. The groups established were as follows (Figure 2 and 4):

A) Both Roman and "Spanish" bricks: absence of raw clay minerals and high newly-formed phase content; no gehlenite was found when there was an abundance of quartz and feldspar. The proportion of vitreous material was fairly high; the vitreous phase was relatively scarce in some of the larger Roman bricks (corner and "sesquipedal" units). Hematite was present as both a primary and a secondary phase.

B) Small number of mainly "Spanish" bricks: significant amounts of mica, kaolinite and amphibole, along with smaller proportions of newly-formed phases and vitreous matter.

Like gypsum, the calcite in groups $A$ and $B$ is probably secondary (possibly originating in the mortar).

C) "Spanish" bricks only: abundance of mica, clay minerals, amphibole and some primary calcite; scarcity of newly-formed phases and minority vitreous material.

The bricks taken from the $15^{\text {th }}$ century tie-bar tower were classified in groups A) and B).

The scanning electron microscopic (SEM) findings for the selected bricks provided details on a number of microstructural features, such as the spatial arrangement of clay particles in the matrix, size and shape of secondary pores, degree of sintering, reaction rims, 
grado de sinterización, bordes de reacción, enlaces entre los granos del degrasante y la matriz, y unión entre las partículas de arcilla y matriz (Figuras 2 y 5). En función de estos rasgos morfológicos se establecen igualmente distintos tipos:

A) Alto grado de sinterización y muchas soldaduras entre distintas fases. Cuando se distinguen, las partículas arcillosas de la materia prima original han perdido su forma laminar y sus bordes están corroidos. Algunas fases neoformadas (silicatos de $\mathrm{Ca}$ ) presentan textura zonal químicamente diferenciada. Otros restos de granos incluidos en las zonas vitrificadas (Figura 5b) presentan, tras su análisis mediante EDS (Figura 5c, ladrillo perteneciente al grupo A) una mineralogía variada: por ejemplo, el punto 1 es sílice, los puntos 2 y 3 son silicatos de $\mathrm{Ca}-\mathrm{Mg}-\mathrm{Al}$, y el punto 4 es $\mathrm{Ca}$ (CaO secundario o restos de calcita?).

B) Sinterización escasa en la matriz y interconexiones limitadas entre los granos del degrasante y la matriz. Los filosilicatos del material de partida conservan su hábito original. Presencia excepcional de fases neoformadas. Algunos granos de plagioclasa tienen bordes enriquecidos en $\mathrm{K}$ [en (7) pueden consultarse datos químicos adicionales, determinados mediante EDS acoplado al SEM].

C) No hay sinterización, ausencia de puentes intergranulares y escasez de fases neoformadas. Preservación de la morfología planar original de los filosilicatos, donde a veces son reconocibles igualmente las exfoliaciones internas.

Respecto a la composición química, los análisis no evidencian diferencias significativas entre los ladrillos romanos y los "españoles", dado que ambos tipos fueron manufacturados usando materias primas arcillosas pobres en Ca (Figura 6), aunque se puede apreciar que los primeros contienen cantidades mayores de Si y Al y menores de $\mathrm{Ca}$, y que la pérdida por calcinación (PPC) es más elevada en los "españoles". La composición química media de los ladrillos de la Torre de la Gran Cadena es intermedia (Figura 6B).

Abundan determinados elementos traza, como $\mathrm{Ba}$, $\mathrm{Sr}$ y $\mathrm{Cr}$ (Figura 7) y se puede discriminar entre ladrillos romanos y "españoles" en base a las proporciones (en ppm) de los mismos; el contenido de V, Ni, Zn, Rb y Zr es bastante similar, por otra parte, en ambos tipos. Las cantidades de $\mathrm{Y}, \mathrm{Sc}, \mathrm{Co}, \mathrm{Cu}, \mathrm{Ga}, \mathrm{Nb}, \mathrm{Pb}$ y Th son bajas (15-50 ppm); el contenido en As y Cs es < 10 ppm, y el de Be, Ge, Sn, $\mathrm{Sb}, \mathrm{Hf}$, Ta, W, Ti y U es < 5 ppm; la cantidad de Mo, Ag, In, y Bi está por debajo de los límites de detección de las técnicas utilizadas. Finalmente, las muestras están relativamente enriquecidas en los elementos ligeros de las tierras raras (LREE) respecto a las pesadas (HREE), detectándose una anomalía en la cantidad de Eu. bridges between aggregate grains and matrix, and welding between clay particles within the matrix (Figures 2 and 5). On the basis of these characteristics, the selected samples were grouped as follows (figures 2 and 5):

A) High degree of sintering and extensive inter-particle welding. The recognizable raw clay mineral particles in the matrix were observed to have lost their lamellar shape and their rims were found to be deteriorated. Some of the newly-formed phases (Ca-Si-silicate) exhibited zones chemically differentiated. Remnants of aggregate grains included in vitreous matter (Figure 5b) were found to have a varying mineralogy, according to EDS analysis (Figure 5c). Point 1 is silica, for instance, while points 2 and 3 are Ca-Mg-Al-silicates and point 4 is Ca (secondary CaO or remains of calcite?).

B) Scarce sintering of the matrix and a small proportion of temper grains/matrix interconnections. The raw clay mineral particles were observed to preserve their initial habitus. The presence of newly-formed phases is exceptional. Some of the plagioclase grains in the aggregate had K-enriched rims; the microchemical details were deduced from EDS and SEM findings (7).

C) No sintering, absence of temper inter-grain bridges and scarcity of newly-formed phases. The raw clay mineral particles in the matrix retained their flat morphology, although some internal exfoliation could be identified.

The chemical analysis revealed no significant differences between the elementary composition of Roman and "Spanish" bricks, both having been manufactured with Ca-poor, clayey raw materials (Figure 6). The Roman bricks had a relatively lower Ca content and higher proportions of Si and Al. Weight loss on ignition (LOI) was higher for "Spanish" bricks. By and large, the chemical composition of the bricks from tie-bar tower was found to be intermediate (Figure 6B).

The differences in the amount ( $\mathrm{ppm}$ ) of some trace elements ( $\mathrm{Ba}, \mathrm{Sr}$ and $\mathrm{Cr}$ ) (Figure 7) were significant enough to distinguish Roman and "Spanish" bricks. On the contrary, V, Ni, Zn, Rb and Zr content was fairly similar in the two types of brick. Very small amounts (15-50 ppm) of $\mathrm{Y}, \mathrm{Sc}, \mathrm{Co}, \mathrm{Cu}, \mathrm{Ga}, \mathrm{Nb}, \mathrm{Pb}$ and Th were found; the figures for As and Cs were < 10 ppm and for $B e, G e, S n, S b$, $H f, T a, W, T i$ and $U<5$ ppm. Mo, Ag, In, and Bi were below the detection threshold. Finally, the samples had a higher light than heavy REE content and the findings for Eu proved to be anomalous. 


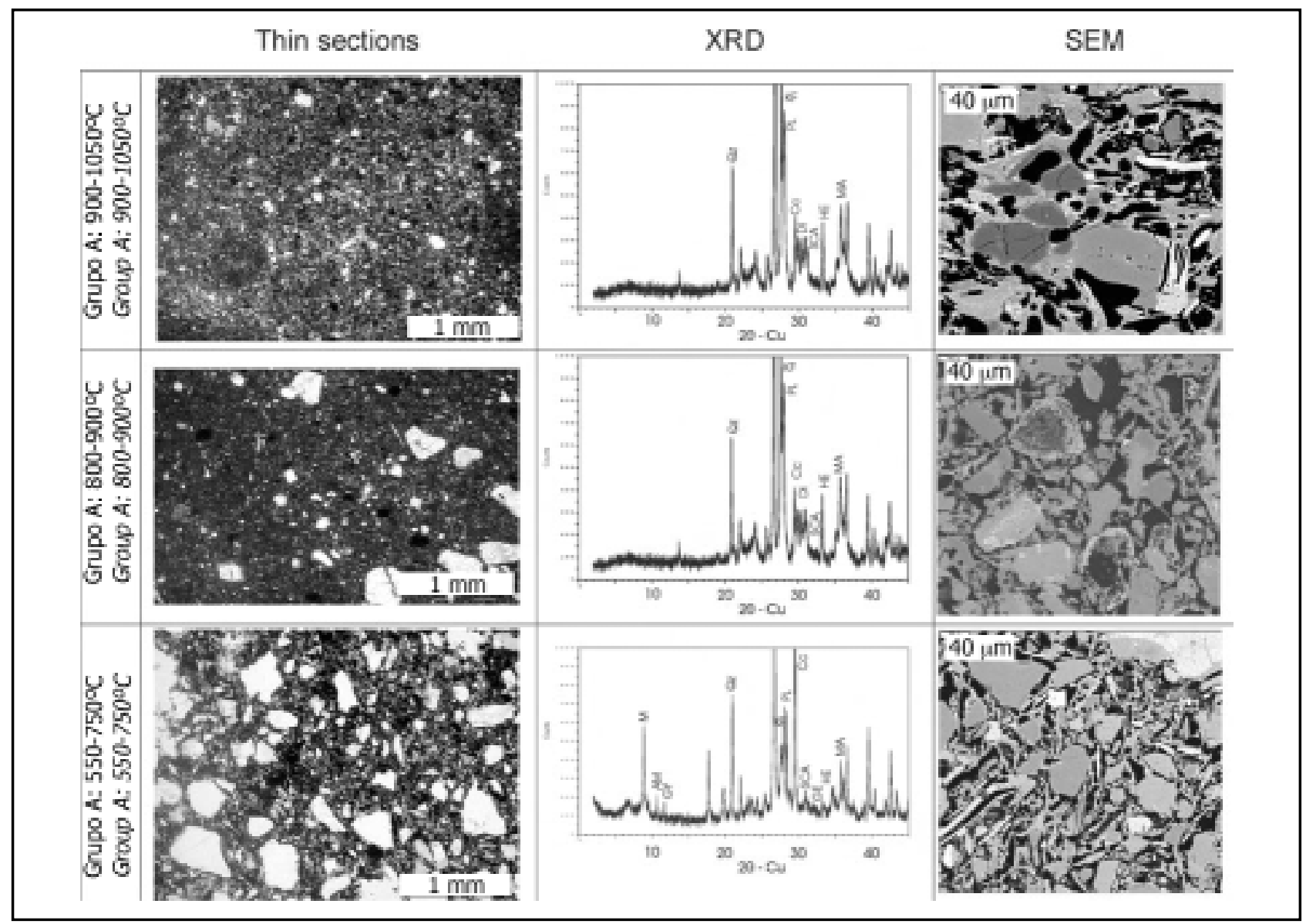

Figura 2. Grupos seleccionados (ver texto).

Figure 2. Selected groups (see text).

\section{DISCUSIÓN}

Los resultados obtenidos indican que los ladrillos "españoles" fueron manufacturados de forma más tosca y con peor selección del material final que los romanos; a la materia prima se le añadió, además, carbonatos y chamota (fragmentos de ladrillos de desecho machacados) como degrasantes, siendo las temperaturas de cocción muy variables. Esta forma de proceder se interpreta como consecuencia de los diferentes destinos para los que se manufacturaron los ladrillos: los dedicados a usos decorativos (puertas de la ciudad y arcos de puentes) requieren mejor calidad y una forma y tamaño adecuado, frente a los meramente defensivos de las murallas.

La composición química de los ladrillos romanos y "españoles" es, por otra parte, bastante similar, y la materia prima usada para su producción (limo arcilloso pobre en $\mathrm{Ca}$, con granos de arena) provino presumiblemente de la misma zona: alrededores de Pavía y/o proximidades de la ribera meridional del río Po $(3,5,7)$. Los ladrillos de la Torre de la Gran Cadena, cuya composición es intermedia, tuvieron con toda seguridad un origen similar.

\section{DISCUSSION}

The results obtained suggest that the process for manufacturing "Spanish" bricks was less refined and entailed a less discriminating selection of the final materials than the Roman variety: they contained added carbonate and aggregate particles consisting of "chamotte" (ground brick). The firing temperatures ranged widely, a finding that may be interpreted in the context of the different intended uses. Bricks for decorative purposes (in town gates and bridge arches), for instance, called for a higher quality product and more precise size and shape than those placed in massive defence walls.

As the chemical and mineralogical composition of Roman and "Spanish" bricks are fairly similar, the source of the raw materials (Ca-poor, clayey-silty with sandy grains) used for their production is presumed to be the same: the area around Pavia and/or near the south side of the Po River (3, 5, 7). The bricks from the tie-bar tower, with an intermediate composition, are also assumed to have been made with these materials. 


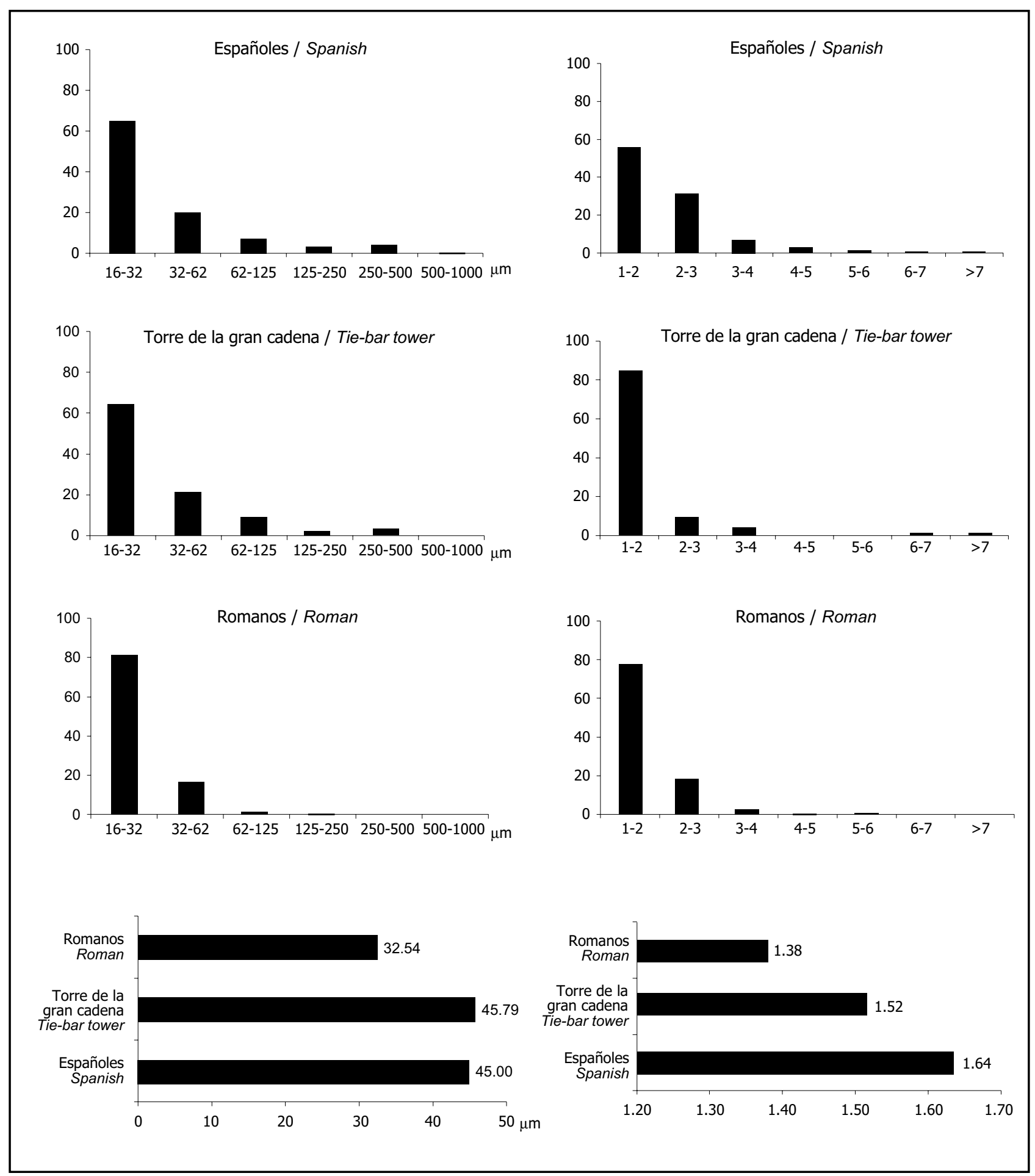

Figura 3. Datos de los granos de degrasante obtenidos mediante análisis de imagen. Figure 3. Computer imaging data of temper (aggregate) grains.

Las cantidades relativamente bajas de Ca observadas en los ladrillos romanos, así como la existencia de algunas anomalías en el contenido de determinados elementos traza, podrían ser debidas a los tratamientos seguidos durante la preparación de los ladrillos (23): tamizaje
The relatively lower Ca-content of Roman bricks and certain differences in trace element content may be due to the treatments used to prepare the green brick (23): sieving (finer particle size) in Roman bricks, addition of carbonate and "chamotte" aggregate in the "Spanish" 


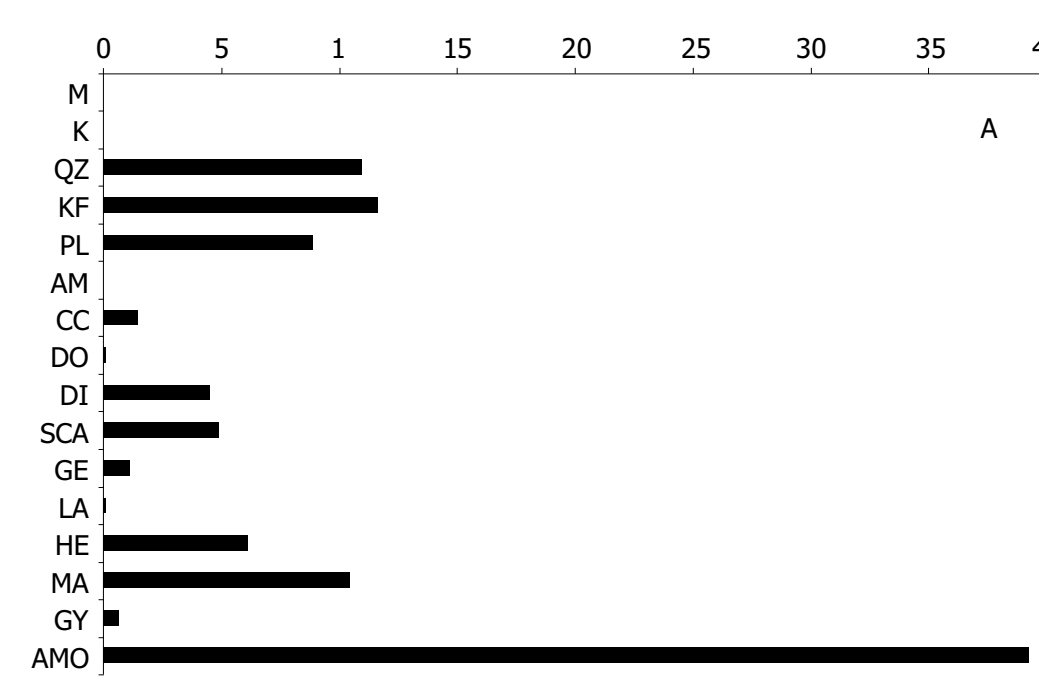

40

A

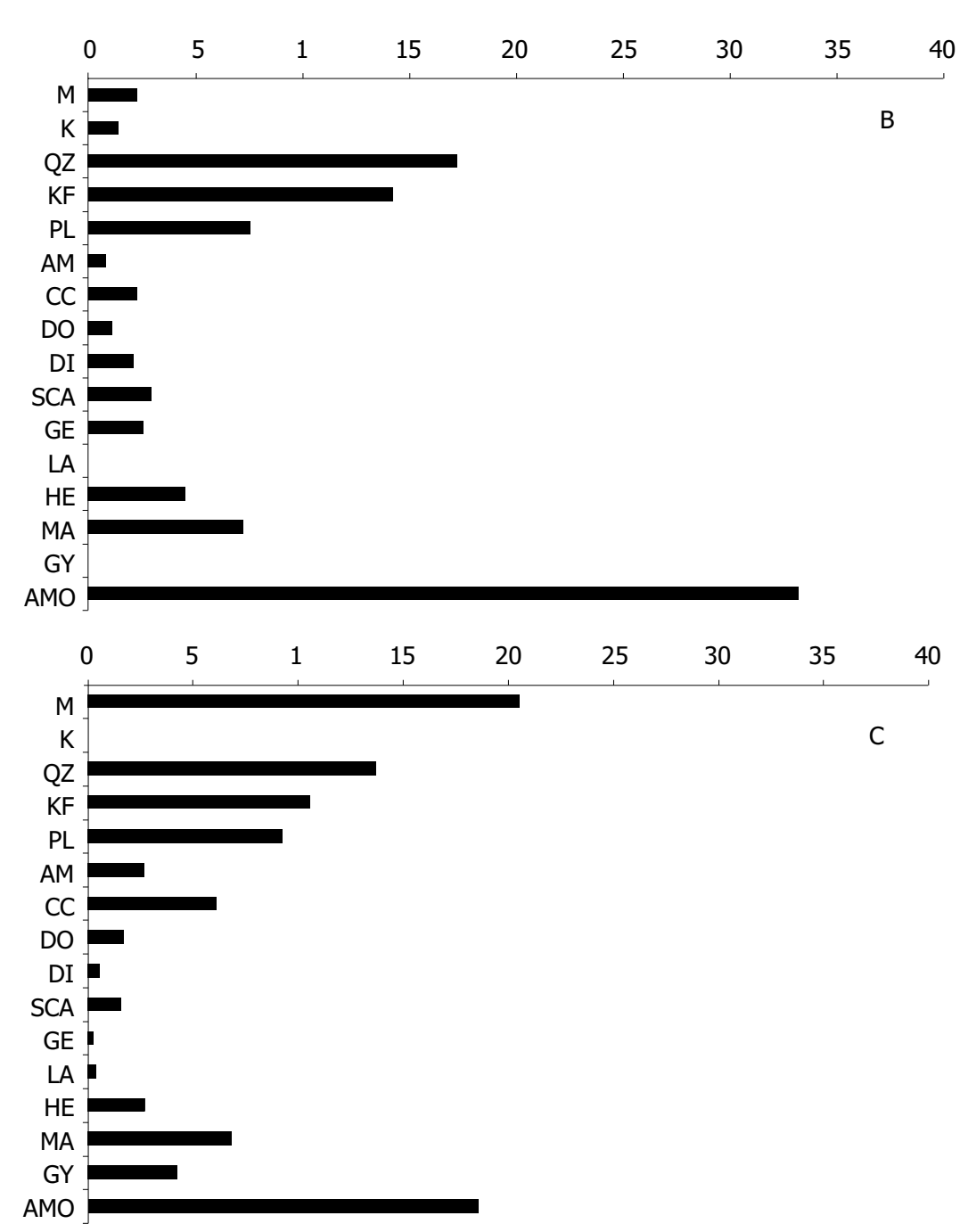

Figura 4. Composición mineralógica (XRD) de los grupos establecidos $\mathrm{A}, \mathrm{B}$ y $\mathrm{C}$.

Figure 4. Mineralogical composition (XRD) of the selected groups $A, B$ and $C$.

Símbolos / Symbols: M = mica / mica, $\mathrm{K}=$ caolinita / kaolinite, $\mathrm{Qz}=$ cuarzo / quartz, $\mathrm{KF}=$ feldespato potásico / $K$-feldspar, $\mathrm{PL}=$ plagioclasa / plagioclase, $\mathrm{AM}=$ anfíbol $/$ amphibole, $\mathrm{CC}=$ calcita $/$ calcite, $\mathrm{DO}=$ dolomita $/$ dolomite, $\mathrm{DI}=$ diópsido $/$ diopside, $\mathrm{SCA}=$ aluminosilicato de Ca / Ca-Al- silicate, GE = gehlenita / gehlenite, $\mathrm{LA}=$ larnita / larnite, $\mathrm{HE}=$ hematites / hematite, $\mathrm{MA}=$ maghemita / maghemite, $\mathrm{GY}=$ yeso / gypsum, $\mathrm{AMO}=$ material amorfo (vitreo) / amorphous (vitreous) matter. 

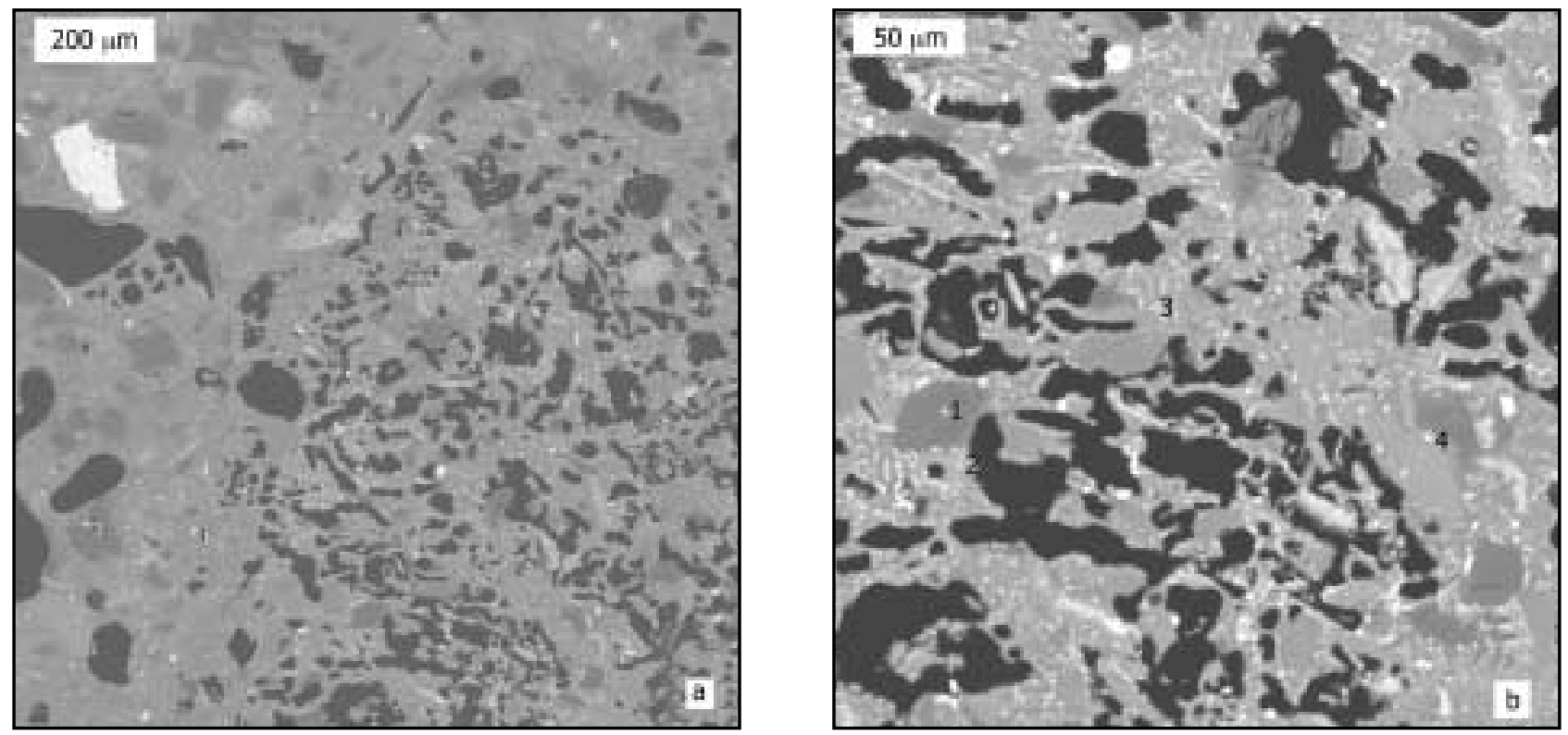

Figura $5 \mathrm{a}$, b. Distintos aspectos de la microporosidad secundaria dentro de zonas vitrificadas y de sinterización de la matriz.

Figure $5 a, b$. Secondary microporosity in sinterized and vitreous areas of the matrix.
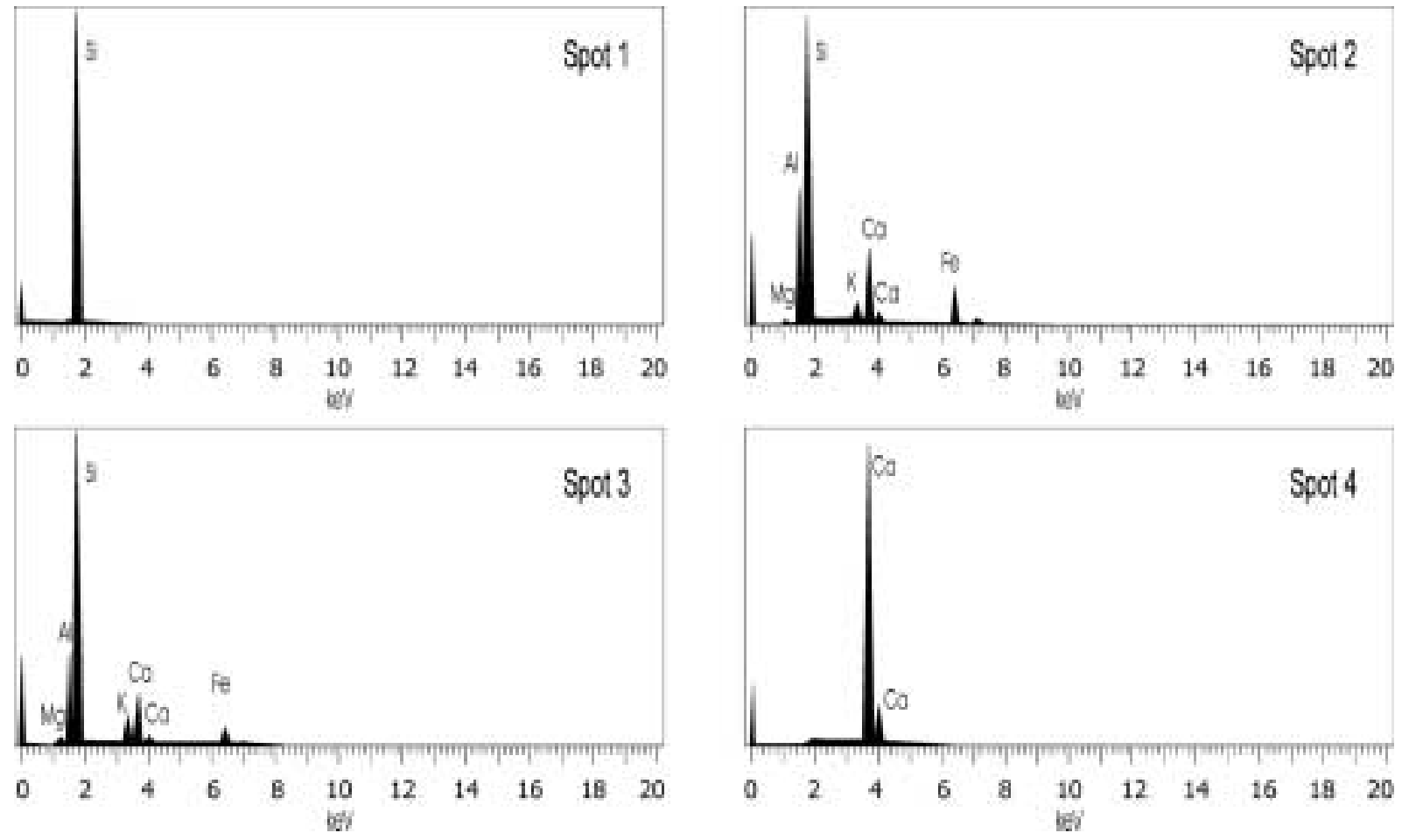

Figura 5 c. Análisis puntuales EDS de restos de agregados granulares localizados en una zona vitrificada (ver Figura $5 b$ ): Figure 5 c. EDS point analyses of residual aggregate grains in a vitreous area (see Figure $5 \mathrm{~b}$ ):

punto $1 /$ point 1 = sílice / silica, puntos 2 y 3 = silicatos de Ca-Mg-Al con algo de $\mathrm{K} /$ points 2 and $3=$ Ca-Mg-Al-silicates containing some $K$, punto $4=\mathrm{CaO}$, restos de calcita / point $4=\mathrm{CaO}$ or residual of calcite. 

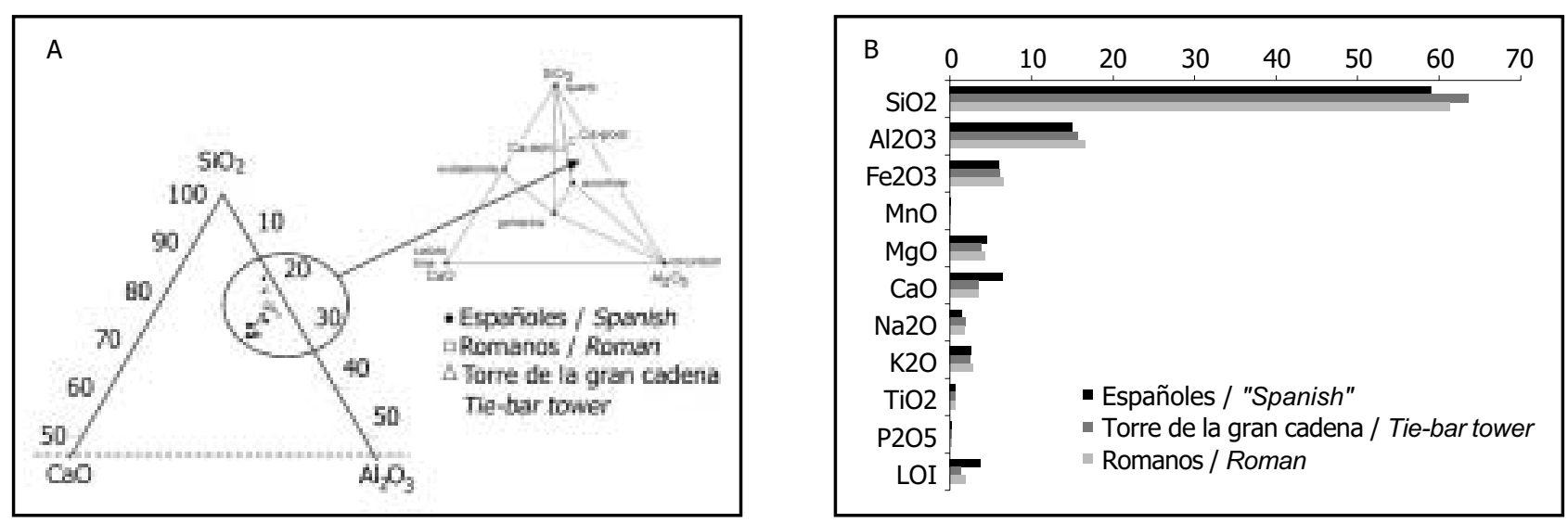

Figura 6. A) Localización de los ladrillos investigados en el diagrama de fases

B) Composición química de las distintas muestras (elementos principales, peso \%), valores medios.

Figure 6. A) Fitting of the investigated bricks in the phase diagram

B) Chemical composition of the different samples (essential elements: weight \%), average values.

para los ladrillos romanos, adición de carbonatos y chamota como degrasante para los "españoles". Queda abierta a debate la explicación para el enriquecimiento en $\mathrm{Cr}$ observado en los primeros.

El color que presentan los ladrillos debe ser consecuencia, por otra parte, de las diferentes mezclas empleadas (presencia de carbonato y oxi-hidróxidos de Fe) y de las condiciones de cocción (temperatura del horno y atmósfera oxidante/reductora), que influenciarían el estado del Fe (24, 25). Así, las tonalidades rojizas o marrón rojizas se deben fundamentalmente a la existencia de pequeños granos dispersos de hematites, generados durante la cocción a partir de las fases de hierro que están presentes en la materia prima original, como goethita, siderita, pirita, etc. Sin embargo, el color que cabría esperar en base al contenido en $\mathrm{Fe}$ no aparecería si este elemento y el calcio se incorporan a fases neoformadas a alta temperatura $(26,27)$. El contenido en $\mathrm{CaO}$ y $\mathrm{Al}_{2} \mathrm{O}_{3}$ tienen influencia, por otra parte, sobre las tonalidades amarillentas o beige de los ladrillos.

El color final tras la cocción parece estar influenciado, además, por la fábrica de la matriz arcillosa, dado que la disposición paralela que adoptan las relativamente rígidas partículas de los filosilicatos no hinchables previene la oxidación del $\mathrm{Fe}^{2+}$, mientras que "tactoides" de partículas expansivas inhiben, en menor medida, dicha reacción, o la deshidroxilación de los hidróxidos de Fe. La hematites se puede acumular igualmente en la superficie de las partículas (28).

Según (29), el color de la materia prima arcillosa sin carbonatos y en condiciones oxidantes varía en función de la temperatura de cocción: naranja claro (Munsell 5YR) entre $500{ }^{\circ} \mathrm{C}$ y $900{ }^{\circ} \mathrm{C}$, naranja rojizo $(2,5 \mathrm{YR})$ entre $900{ }^{\circ} \mathrm{C}$ y $1.100^{\circ} \mathrm{C}$ y marrón rojizo (10R) a temperaturas superiores a $1.100{ }^{\circ} \mathrm{C}$. El color rojizo va ligado igualmente, como ya se ha comentado, a la hematites material. The explanation for the higher $\mathrm{Cr}$ content in the Roman bricks remains open to debate.

Differences in brick colour may be the result of both blending (presence of carbonate and Fe-oxy-hydroxides) and firing conditions (kiln temperature and oxidizing/reducing atmosphere), which determine the (ferrous or ferric) form of the Fe ion $(24,25)$. Shades of red or reddish-brown are indicative of the existence of the fine-grained, dispersed hematite that develops from raw iron minerals (goethite, siderite, pyrite, etc.) during firing. Post-firing colours that would be expected from the Fe content of the raw materials may fail to materialize, however, due to the incorporation of iron (and calcium) in specific high-temperature crystalline newly-formed phases (26, 27). Conversely, the $\mathrm{CaO}$ and $\mathrm{Al}_{2} \mathrm{O}_{3}$ content may impact brick colour (yellow or beige).

Firing colour also appears to be affected by the clay matrix structure and texture, for the parallel layout adopted by the relatively rigid, non- or only slightly expandable clay particles may prevent $\mathrm{Fe}^{2+}$ oxidation, whereas "tactoids" of expansive particles may be less effective inhibitors of $\mathrm{Fe}^{2+}$ oxidation or dehydroxylation of Fe-hydroxides. Moreover, hematite may accumulate on particle surfaces (28).

According to (29), under oxidizing conditions, the colour of carbonate-free clayey raw materials may depend on the firing temperature: $500-900{ }^{\circ} \mathrm{C}$ (light orange $=$ Munsell $5 Y R$ ), $900-1,100{ }^{\circ} \mathrm{C}$ (orange-red $=2.5 \mathrm{YR}$ ) and $>1,100{ }^{\circ} \mathrm{C}$ (red-brown $\left.=10 R\right)$. Red hues can be attributed to hematite neoformation, whereas shades of duskyblack are indicative of the presence of maghemite 


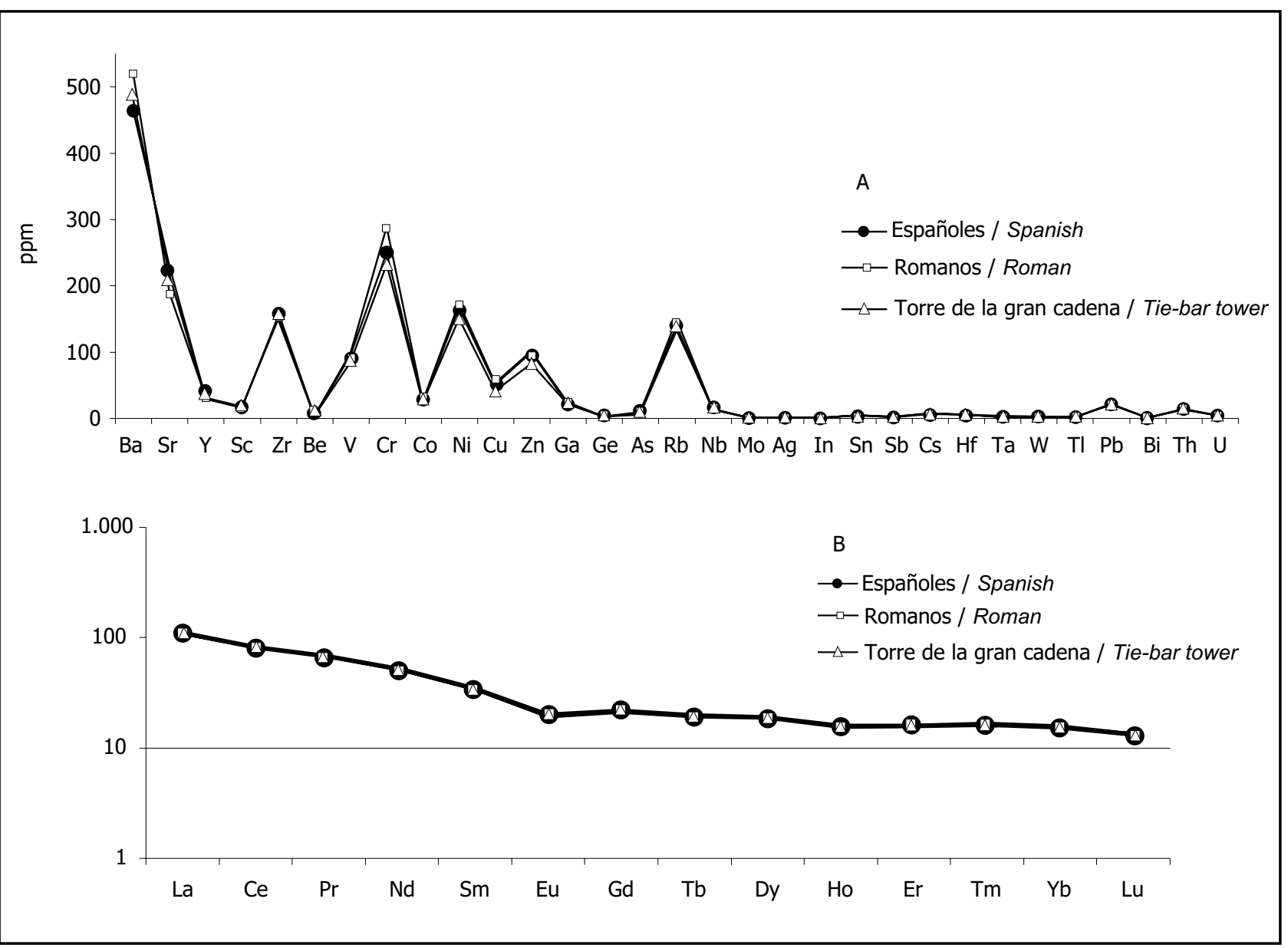

Figura 7. A) Elementos menores y traza; B) Tierras raras (valores medios).

Figure 7. A) Minor and trace elements; B) Rare earth elements (mean values).

neoformada, en tanto que la maghemita $\left(\gamma-\mathrm{Fe}_{2} \mathrm{O}_{3}\right)$ da lugar a tonalidades negruzco-oscuras. Esta última fase es muy común en suelos de zonas que han sufrido incendios, y se ha sugerido (30) que el simple calentamiento de los oxi-hidróxidos de Fe pueden producir maghemita, como consecuencia del efecto reductor ligado a la presencia de materia orgánica, lo cual origina maghemita en vez de hematites, tal y como ha sido comprobado en experiencias de laboratorio. Cuando se emplea madera "verde" en el horno de cocción, la transformación en maghemita de la goethita, lepidocrocita y ferrihidrita presente en el material arcilloso de partida podría ocurrir a temperaturas superiores a $300{ }^{\circ} \mathrm{C}$, dado que el humo generado por la combustión de dicha madera crea una atmósfera reductora. Son bien conocidas, además, las alternancias en las condiciones redox de los hornos de cocción empleados durante la Edad Media.

Dada la localización sumergida o muy próxima a las aguas del río Ticino de algunos de los ladrillos estudiados, los cambios en el color original se ven influenciados, igualmente, por distintos procesos de lavado e impregnación,
$\left(\gamma-\mathrm{Fe}_{2} \mathrm{O}_{3}\right)$. This phase is common in soils burnt during bushfires, and it has been suggested (30) that maghemite can be generated by simply heating Fe-oxy-hydroxides; such a transformation may be the result of chemical reduction due to the presence of organic matter, which leads to the formation of maghemite rather than hematite. This hypothesis has been supported by successful laboratory synthesis. The generation of maghemite from the goethite, lepidocrocite and ferrihydrite present in raw materials used for producing bricks may occur in the kiln at $T>300{ }^{\circ} \mathrm{C}$ when "green" wood is used for firing, because of the reducing atmosphere created by the smoke emitted by this fuel. Moreover, alternating redox conditions are known to have prevailed in Medieval firing kilns.

Changes in the initial colour may also be due to leaching/impregnation, such as in bricks from the (Roman) bridge piles and the tie-bar tower sunk in the river bed. The phase clusters detected $(29,31,32,33)$, particularly 
como es el caso de aquellos pertenecientes a los pilares del puente romano y los de la Torre de la Gran Cadena. En base tanto a las asociaciones de fases que se han detectado $(29,31,32,33)$, especialmente en los ladrillos manufacturados con materia prima rica en calcio $(34,35$, $36)$, como a las texturas observadas $(37,38)$, podemos indicar que se emplearon distintas temperaturas de cocción durante el proceso de fabricación:

A) 900 - $1.050{ }^{\circ} \mathrm{C}$ : ladrillos romanos y "españoles", caracterizados por la presencia de numerosos granos de degrasante con bordes de reacción y soldaduras, vitrificación de la matriz, desaparición de micas, gehlenita, diópsido, silicatos-Ca-Al (y no wollastonita) como fases neoformadas, eventual ausencia de gehlenita. Entre los feldespatos, la plagioclasa resulta estable a temperaturas más elevadas que el feldespato potásico, de forma que la destrucción de éste contribuye a la aparición de bordes ricos en $\mathrm{K}$ en los granos resistentes de plagioclasa. Se detectan zonas de vidrio con porosidad secundaria sellada, de tamaño variable (Figura 5) $(37,43)$ (llamada "estructura celular" por 54).

B) 800 - $900{ }^{\circ} \mathrm{C}$ : algunos ladrillos "españoles" y unos pocos romanos: en este tipo de ladrillos aparecen dañados los filosilicatos de la matriz (mica isotrópica), la calcita se ha descompuesto y la caolinita ha desaparecido. La escasa proporción de aluminosilicatos con $\mathrm{Ca}$ que hemos detectado es indicativa de reacciones incipientes entre la sílice y los carbonatos; la formación de diópsido, por otra parte, puede ocurrir hasta $950{ }^{\circ} \mathrm{C}$, lo que afecta igualmente a la gehlenita previamente neoformada. Un indicador adicional de este rango de temperaturas de cocción es la presencia de pequeñas zonas vitrificacas.

C) (550) 600 - (750) 800 C: sólo ladrillos "españoles": en ellos se han preservado las características primarias de los minerales de la arcilla y las micas. Aunque la presencia ocasional de gehlenita indicaría una temperatura en torno a $800{ }^{\circ} \mathrm{C}$ (39), tanto el gradiente termal como el tamaño de grano de la calcita que reacciona (40) tendrían influencia en la formación de esta fase. La persistencia de gehlenita hasta $1.050^{\circ} \mathrm{C}$ ha sido interpretada como una peculiaridad in situ de la calcita, que favorece la estabilidad de la gehlenita neoformada $(48,49)$. Se ha sugerido igualmente (41) que la gehlenita se genera más fácilmente que los piroxenos a causa de la diferente coordinación del Al tetra y octehédrico (42). La granulometría de la pasta de partida tendría, por su parte, influencia en el escape de fases gaseosas (como vapor y $\mathrm{CO}_{2}$ ) durante los procesos de secado y cocción $(33,43)$. La pérdida por calcinación es más elevada en los ladrillos "españoles", cuya granulometría es más grosera. Finalmente, la tonalidad más clara en el color de este tipo de ladrillos y la in bricks made with Ca-bearing raw materials (34, 35, $36)$, and the textures observed $(37,38)$ are indicative of several ranges of firing temperatures.

A) 900 - 1,050 'C: Both Roman and "Spanish" bricks: characterized by aggregate particles showing reaction rims, bridges, matrix welding and vitrification; absence of mica; presence of newly-formed phases consisting in gehlenite, diopside and Ca-Al-silicates, although gehlenite was absent in some cases; no wollastonite detected. Of the feldspars, plagioclase was stable at a relatively higher temperature than $K$ feldspar; the deterioration of the latter may have contributed to the formation of K-rims around the more durable plagioclase particles. Some vitreous areas (Figure 5) exhibit secondary sealed pores of variable size $(37,43)$, described as a "cellular structure" (54).

B) 800 - 900 ०C: Some "Spanish" and a short number of Roman bricks: matrix clay minerals are damaged (isotropized mica), calcite decomposes and kaolinite disappears. The scant presence of Ca-Al-silicates is indicative of incipient silica-carbonate reactions; furthermore, diopside may form up to temperatures of $950{ }^{\circ} \mathrm{C}$, likewise affecting newly-formed gehlenite (which appears before diopside). The existence of small patches of vitrified material is another sign characteristic of bricks fired in this temperature range.

C) (550) 600 - (750) 800 C: "Spanish" bricks only: the main properties of minerals and micas remain unchanged. The sporadic presence of gehlenite may indicate that the temperature reached $800^{\circ} \mathrm{C}$ (39), although the effect of the thermal gradient should not be overlooked. Gehlenite formation is also contingent upon the particle size of the reactive calcite (40). The persistence of gehlenite at temperatures of up to $1,050{ }^{\circ} \mathrm{C}$ has been interpreted as an in situ peculiarity of calcite which enhances the stability of newly-formed gehlenite $(48,49)$. It has also been suggested (41) that gehlenite may be more readily generated than pyroxenes because of the difference between tetra- and octahedral Al coordination (42). The particle size distribution in "green" brick impacts the release of gaseous phases (such as water vapour and $\mathrm{CO}_{2}$ ) during the drying and firing processes $(33,43)$. Notably, loss on ignition (LOI) is higher in "Spanish" bricks, which have a coarser particle size. Both the lighter colour of and the presence of carbonates in "Spanish" bricks are characteristics 
existencia de carbonatos serían otros criterios adicionales que soportan la hipótesis de una temperatura de cocción inferior.

Los ladrillos de la Torre de la Gran Cadena se incluyen en el grupo de cocción a temperaturas $800-900{ }^{\circ} \mathrm{C}$ y 900 $1.050{ }^{\circ} \mathrm{C}$.

\section{OBSERVACIONES}

La naturaleza de la materia prima empleada, su proveniencia y la tecnología de los materiales cerámicos antiguos necesitan un estudio integrado para evitar discrepancias en la interpretación de los resultados $(33,44)$. La mejora y disponibilidad de las técnicas analíticas han contribuido a una mejor caracterización y reconstrucción de los diferentes métodos de producción de los ladrillos.

Las interacciones entre varias fases que coexisten, desaparecen o se neoforman es todavía una materia de debate. Poco se sabe, además, de las reacciones entre las superficies externas de distintas fases, y no se entienden muy bien los mecanismos de transporte de los reactivos (i.e., difusión versus transporte de masa, fluido y/o flujo viscoso), ni sobre los procesos implicados en las transformaciones minerales a alta temperatura (i.e., reacciones de estado sólido versus cristalización a partir de fundido). Por otra parte, los minerales de la arcilla sufren algunas reacciones características (deshidroxilación, descomposición y transformación) que pueden usarse como "termómetros arqueológicos" (45). En consecuencia, la paragénesis de estos materiales artificialmente metamorfizados puede contener asociaciones de fases no comunes en contextos naturales, que hace difícil entender el "curso" de las reacciones.

Las técnicas de XRD y SEM presentan algunos inconvenientes: la primera informa sobre la composición mineral media de una mineralogía quizás heterogénea, y la segunda tiene una resolución espacial baja. Un comentario similar es aplicable para las modificaciones observadas en la "fábrica" original, debido a los gradientes dinámicos y a las condiciones redox existentes en el material arcilloso durante la cocción. Por el contrario, el estudio mediante TEM permite visualizar partículas cripto-microcristalinas, nano-inclusiones y componentes (pseudo) amorfos, con ampliaciones próximas a resolución atómica, lo que facilita el detallar distintos procesos de reacción. Así pueden diferenciarse, por ejemplo, fases intermedias de esmectitas, interestratificados illita/esmectita, illita $u$ otras micas siguiendo un gradiente de temperatura $(46,47)$.

Los cambios mineralógicos y de "fábrica" ocurren probablemente en sistemas desequilibrados a pequeña escala, providing further support for a relatively low firing temperature.

The bricks taken from the $15^{\text {th }}$ century tie-bar tower were fired at 800-900 and 900-1,050 ${ }^{\circ} \mathrm{C}$.

\section{FURTHER COMMENTS}

An integrated approach must be adopted in the study of the composition, place of origin and technology of ancient fired clay materials to avoid discrepancies in the interpretation of the results $(33,44$ and 44 bis). Improvements in and readier accessibility of analytical methods and facilities have enhanced the characterization and reconstruction of brick production processes used in the past.

The interactions between co-existing, newly-formed and disappearing phases are still a matter for debate. Little is known about reactions at the interface, and there is no clear understanding of either reagent transport mechanisms (i.e., diffusion versus mass transport, fluid and/or viscous flow) or the processes involved in mineral transformations at high temperatures (i.e., solid-state reactions versus crystallization from molten matter). Clay minerals, for instance, exhibit a number of characteristic reactions (dehydroxylation, decomposition and transformation) that can be used as "archaeological thermometers" (45). Nonetheless, paragenesis in these artificially thermo-metamorphosed materials may lead to phase clusters that are unusual in natural contexts, making it more difficult to understand reaction mechanisms.

There are, moreover, drawbacks to XRD and SEM: in the former the results are merely an average of heterogeneous components and in the latter the spatial resolution is relatively low. A similar comment may be made with regard to the changes observed in the initial structuretexture, in light of the gradient dynamics and redox conditions taking place in the clayey matrix throughout the firing process. TEM, by contrast, can image cryptomicrocrystallites, nano-inclusions and (pseudo)amorphous components at a magnification near atomic resolution, affording a more detailed view of the reactions. Intermediate phases of smectite, mixed-layer illite/smectite, illite and mica can be differentiated by means of the temperature gradient $(46,47)$, for instance.

Mineralogical and structural-textural changes probably occur locally in systems with small-scale imbalance, in 
y la cinética sería, en este caso, un factor importante a tener en cuenta $(48,49,50)$, dado que se producen reacciones "modales" (nucleación y crecimiento de nuevas fases) y reacciones "cripto" (que sólo dan lugar a variaciones composicionales zonales en fases preexistentes). Las fases fluidas y la presión efímera que ejercen en los poros influencian, igualmente, la cinética de las reacciones $y$, en consecuencia, la composición de las fases neoformadas no corresponde al gradiente termal del horno. En estas circunstancias no es adecuado, por tanto, el uso de "diagramas de barras", como propone (15).

Las modificaciones microestructurales y texturales ("fábrica") ocurridas en los ladrillos durante su proceso de cocción son importantes para distinguir y comprender distintos cambios progresivos $(37,38,52)$. De hecho, la exfoliación y contracción (entre 600 y $800^{\circ} \mathrm{C}$ ), sinterización y vitrificación (entre $800-1.000^{\circ} \mathrm{C}$ ) y evolución de la porosidad (por encima de $1.000{ }^{\circ} \mathrm{C}$ ) son función de la temperatura de cocción. Además, a temperaturas crecientes, se puede formar una fase líquida que tapone progresivamente los poros de tamaño más pequeño, incrementando así la porosidad sellada. El agrandamiento de los poros de mayor tamaño ocurre a $\mathrm{T}>1.000^{\circ} \mathrm{C}$ como consecuencia de la expansión de gases inicialmente atrapados o provenientes de reacciones de ruptura (53).

Si se llegaran a plantear intervenciones de restauración tales como reparaciones, reemplazamientos o reconstrucciones se debería tener en cuenta el tipo de materia prima a emplear y las condiciones de cocción de los ladrillos que se realizan en la actualidad.

Dado que la degasificación de los carbonatos durante la cocción ejerce una clara influencia sobre la cantidad, distribución y volumen de los poros, los ladrillos fabricados con material no carbonatado deberían, por tanto, ser de mejor calidad. Además, el carbonato residual puede transformarse en portlandita, una fase de mayor volumen, cuya cristalización genera presión en espacios confinados, lo que favorece la aparición y desarrollo de fracturas.

La porosidad está ligada, por otra parte, a la absorción de humedad y condiciona el comportamiento del material ante las heladas, afectando, por tanto, la durabilidad y resistencia a la meteorización de los ladrillos $(55,56)$. La fábrica vítrea de la matriz le confiere mayor resistencia a los procesos de degradación. Otros factores que afectan la conservación y/o degradación de los ladrillos son la composición mineral de la materia prima, la temperatura de cocción, la localización de los mismos dentro de un muro concreto (exposición aérea o soterramiento) y la acción de agua de filtración natural o contaminada (57).

El clima de la región de Pavía (58) constituye un parámetro específico que debe tenerse en cuenta para el devenir which kinetics would be an important factor $(48,49,50)$ in determining whether "modal" (nucleation and newphase growth) or "crypto" (involving only zonal variations in the composition of pre-existing phases) reactions take place. Furthermore, since fluid phases and the transient pore pressure they exert impact reaction kinetics, the composition of the phases formed may not correspond to the thermal gradient in the kiln. The use of "bar graphs" as proposed by (51) would not, therefore, be suitable under such circumstances.

Microstructural-textural modifications induced by firing are important for detecting and understanding the progressive changes in the brick body $(37,38,52)$. Exfoliation and shrinking $\left(600-800^{\circ} \mathrm{C}\right)$, sintering and vitrification $\left(800-1,000^{\circ} \mathrm{C}\right.$ ) and porosity (over $1,000^{\circ} \mathrm{C}$ ) are in fact dependent on firing temperature. In addition, as the temperature rises, a liquid phase may form that progressively closes smaller pores and increases sealed porosity. The larger pores grow in size at $T>1,000{ }^{\circ} \mathrm{C}$ as a result of the expansion of gases, which may have been initially entrained or generated during chemical decomposition (53).

The raw materials and firing conditions used to manufacture modern bricks must be taken into account in restoration works such as the repair, replacement or reconstruction of ancient monuments.

Since carbonate degassification during firing impacts pore size distribution, bricks made with carbonate-free clayey raw materials are of higher quality in this regard. Residual lime may evolve into portlandite, a phase whose larger volume generates crystallization pressure in confined spaces, inducing cracks.

Porosity affects brick performance in terms of moisture absorption and frost resistance and therefore its durability and weatherability $(55,56)$. A vitreous matrix enhances the material's resistance to degradation. The mineralogical composition of raw materials, firing temperature, location (exposure to either aerial or underground environments) and the action of natural or polluted filtration water all impact brick conservation-degradation (57).

One specific parameter to be taken into account in connection with the future performance of the bricks studied 
de los ladrillos investigados. Aunque ha cambiado algo durante las últimas décadas debido a la contaminación del aire, se puede considerar esencialmente como pseudomonzónico, con máximos de lluvia en primavera y otoño. Características peculiares del mismo son, además, la alta humedad ambiental que existe durante el verano (alcanza hasta el $85-90 \%$ ) como consecuencia de la evaporación del agua estancada en los campos de cultivo de arroz, muy extendidos en la región, una niebla persistente durante periodos prolongados, tanto en otoño como en invierno, y varios ciclos de temperaturas bajo $0{ }^{\circ} \mathrm{C}$ (días con heladas) durante el invierno (de hecho, las nevadas se han reducido drásticamente durante los últimos tiempos), mientras que los días soleados son unos 260 por año, con aproximadamente 40 días "tropicales" ( $\mathrm{T}>30^{\circ} \mathrm{C}$ ). Todo ello tiene una clara influencia en el comportamiento de los materiales de construcción, especialmente aquellos más porosos como es el caso de los ladrillos ( $y$ areniscas, piedras carbonatadas, morteros, yesos o repellados), lo que se aprecia con claridad en muchas construcciones históricas y modernas de Pavía.

\section{AGRADECIMIENTOS}

Nos sentimos en deuda con la Dra. Donata Vicini, directora del Museo Cívico de Pavía, por las facilidades prestadas para la consulta de la documentación histórica, y con el Dr. Federico Carò (Departamento de Ciencias de la Tierra, Universidad de Pavía) por su ayuda durante el proceso de análisis de imagen. Distintos comentarios realizados por el Dr. Giuseppe Cultrone (Departamento de Mineralogía y Petrología, Universidad de Granada) han mejorado el texto. is the climate in the region of Pavia (58). Although it has changed over the last few decades due to air pollution, it is primarily pseudo-monsoonal, with heavy rainfall in the spring and autumn. Other characteristic features are high humidity during the summer (up to 85-90\%) due to the evaporation of standing water from the region's widespread rice-fields, and persistent fog in the autumn and winter. In addition, while the mercury drops to around $0{ }^{\circ} \mathrm{C}$ ("frost" and "ice" days) several times every winter (despite the drastic decline in snowfall over the last few decades), there is an average of 260 sunny days and about 40 very warm $\left(T>30^{\circ} \mathrm{C}\right)$ days per year. Such a climate takes a heavy toll on building materials, particularly porous materials such as brick (not to mention sandstone, limestone, mortar and plaster), as revealed by many of Pavia's historic and modern buildings.

\section{ACKNOWLEDGEMENTS}

The authors are indebted to Dr. Donata Vicini, Director of the Civic Museum of Pavia, for her help with the historical documentation, and to Dr. Federico Carò (Department of Earth Sciences, University of Pavia) for his assistance with computer imaging. Conversations with Dr. Giuseppe Cultrone (Department of Mineralogy and Petrology, University of Granada, Spain) led to distinct improvements in the manuscript. An anonimous reviewer improved our english.

\section{BIBLIOGRAFÍA / BIBLIOGRAPHY}

(1) Lodola, S.: Studio archeometrico di laterizi e malte dallo scavo archeologico di Villa Maria (Lomello, prov. di Pavia). Graduation Thesis, Univ. Pavia, 1993.

(2) Lodola, S., Setti, M. y Veniale, F.: "Studio archeometrico delle malte romane e medievali dallo scavo archeologico di Lomello (PV)", Ceramica Informazione, 1997, I (367), 26-30; II (368), pp. 94-100.

(3) Cairo, A.: Ricerche mineralogiche, petrografiche e geochimiche applicate allo studio archeometrico. Le materie prime utilizzate per la produzione di ceramiche in epoca romana. PhD Thesis, Univ. Pavia, 1998.

(4) Veniale, F., Zezza, U., Setti, M. y Tortelli, M.: Analisi mineralogico-petrografiche eseguite su materiali della Torre Civica e di altre Torri medievali (San Dalmazio e Belcredi) in Pavia. Relazione "Commissione tecnico-scientifica per l'esame delle cause del crollo della Torre Civica di Pavia e indagine sullo stato di conservazione di altri monumenti cittadini circostanti"; Presidenza Consiglio dei MinistriUfficio Protezione Civile, 1992, pp. 233-270.

(5) Pearce, M., Meloni, S., Setti, M., Genova, N., Oddone, M. y Muggia, A.: "A multidisciplinary investigation of Roman bricks from the Torre Civica of Pavia (NW Italy)", Sci. Tech. Cultural Heritage, 5 (1996), pp. 19-27.

(6) Setti, M. y Veniale, F.: "I materiali usati per la costruzione della Torre Civica di Pavia. Loro condizioni e ruolo nelle cause del crollo", Boll. Soc. Pavese Storia Patria, 99 (1999), pp. 479-488.

(7) Nicola, C.: Studio archeometrico di laterizi utilizzati per la costruzione delle cinture murarie nella città di Pavia di epoca Romana e Spagnola. Graduation Thesis, Univ. Pavia, 2002.

(8) Galandra, M.: Storia di Pavia (dalle origini all'Unità d'Italia), G. Iuculano ed., 2000.

(9) Gianani, F.: Le mura e le porte di Pavia antica, Ed. AVIS Pavia, 1983.

(10) Arecchi, A.: I bastioni di Pavia, Litografia Abbiatense, 1999. 
(11) Fagnani, F.: "Il tracciato delle mura Romane di Ticinum", Boll. Soc. Pavese Storia Patria, 59 (1959), pp. 3-42.

(11 bis) Gaiotti, N.: La Torre del catenone. Storia di un fortilizio fluviale, Ed. Aurora, Pavia, 1989.

(12) Veniale, F.: Modern techniques of analysis applied to ancient ceramics, Proc. Advanced Workshop ICOMOS-CE "Analytical methodologies for the investigation of damaged stones", Pavia. [F. Veniale and U. Zezza (eds.)], 1990, pp. 1-45.

(13) Tucker, M.: Techniques in sedimentology, Blackwell, 1988.

(14) Wilson, M. J. (ed.): Handbook of determinative methods on clay mineralogy, Blackie-Chapman, 1987.

(15) Jerram, D. A.: "Visual comparators for degree of grain-size sorting in two and three dimensions", Computer \& Geoscience, 27 (2001), pp. 485-499.

(16) Terry, R. D. y Chilingar, G. V.: "Summary of 'Concerning some additional aids in studying sedimentary formations' " (by M. S. Shretsor), J. Sed. Petr., 25 (1955), pp. 229-234.

(17) "Munsell's Rock Color Chart", Geol. Soc. Amer., 1951 (2nd printing).

(18) Kempe, D. R. C. y Harvey, A. P.: The petrology of archaeological artefact, Claredon, 1983.

(19) Wenk, H. R. (ed.): Electron microscopy in mineralogy, Springer, 1976.

(20) Tite, M. S.: "The impact of electron microscopy on ceramic studies", Proc. Brit. Acad, 77 (1992), pp. 111-131.

(21) Carò, F.: Characterization of mortars and plasters through image analyses. PhD Thesis, Univ. Pavia, 2004.

(22) Huertas, J., Huertas, F. y Linares, J.: "Evaluación de las fases no-cristalinas en ceramicas arqueologicas por DRX", Bol. Soc. Esp. Miner., 14 (1991), pp. 71-78.

(23) Kilikoglou, V., Maniatis, Y. y Grimanis, A. P.: "The effect of purification and firing of clays on trace element provenance studies", Archaeometry, 30 (1988), pp. 37-46.

(24) Heimann, R. B., Maggetti, M. y Einfalt, H. C.: "Zum Verhalten des Eisens beim Brennen kalkhaltigen illitischen Tons unter reduzierenden Bedingungen", Ber. dtsch Keram. Ges., 57 (1980), pp. 145-152.

(25) Maniatis, Y., Simopoulos, A. y Kostikas, A.: "Effect of reducing atmosphere on minerals and iron oxides developed in fired clays. The role of calcium", J. Amer. Ceram. Soc., 66 (1983), pp. 773-781.

(26) Kreimeyer, R.: "Some notes on firing colours of clay bricks", Appl. Clay Sci., 2 (1987), pp. 175-183.

(27) Molera, J., Pradell, T. y Vendrell-Saz, M.: "The colour of Ca-rich ceramic pastes: origin and characterization", Appl. Clay Sci., 13 (1998), pp. 187-202.

(28) Stepkowska, T. y Jefferis, A.: "Influence of microtexture on firing colour of clays", Appl. Clay Sci., 6 (1992), pp. 319-342.

(29) Wolf, S.: "Estimation of the production parameters of very large medieval bricks from St. Urban, Switzerland", Archaeometry, 44 (2002), pp. 37-65.

(30) Grogan, K. L., Gilkes, R. J. y Lottermoser, B. G.: "Maghemite formation in burnt plant litter", Clays \& Clay Miner., 51 (2003), pp. $390-396$.

(31) Maggetti, M.: "Phase analysis and its significance for technology and origin", en Olin, J. S. y Franklin, A. D. (eds.): Archaeological ceramics, Smithsonian Inst. Press (1982), pp. 121-133.

(32) Tite, M. S.: Firing temperature determinations. How and why?, KVHAA Konf., Stockholm, 34, 1995, pp. 37-42.

(33) Veniale, F.: "Raw materials and manufactoring processes of ancient ceramic artefacs", Proc. Eur. Workshop on Archaeological Ceramics, Roma (1994), pp. 55-71.

(34) Peters, T. J. y Iberg, R.: "Mineralogical changes during firing of Ca-rich brick clay", Amer. Ceram. Soc. Bull., 57 (1978), pp. 503-506.

(35) Gonzales-García, F., Romero-Acosta, V., García-Ramos, G. y Gonzales-Rodrígues, M.: "Firing transformations of mixtures of clays containing illite, kaolinite and calcium carbonate", Appl. Clay Sci., 5, 1990, pp. 361-375.

(36) Cultrone, G., Rodríguez-Navarro, C., Sebastián, E., Cazalla, O. y De La Torre, M. J.: "Carbonate and silicate phase reactions during ceramic firing", Eur. J. Miner., 13 (2001), pp. 621-634.

(37) Orts, M. J., Escardino, A., Amorós, J. L. y Negre, F.: "Microstructural changes during the firing of stoneware floor tiles", Appl. Clay Sci., 8 (1993), pp. 193-205.

(38) Delbrouck, O., Janssen, J., Ottenburgs, R., Van Oyen, P. y Viaene, W.: "Evolution of porosity in extruded stoneware as a function of firing temperature", Appl. Clay Sci., 8 (1993), pp. 187-192.

(39) Maggetti, M. y Heimann, R. B.: "Bindung und Stabilität von Gehlenit in Romischer Feinkeramik", Schweiz. Miner. Petr. Mitt., 59 (1979), pp. 413-417.

(40) Jelinski, M.: "Zur Korngrössenabhängigkeit der Gehlenitbildung", Meldearbeit Miner. Petr. Inst. Univ. Freiburg-Schweiz, 1981, $21 \mathrm{pp}$.

(41) Huckenholz, H. G.: "Gehlenite stability relations in the join $\mathrm{Ca}_{2} \mathrm{Al}_{2} \mathrm{SiO}_{7} \cdot \mathrm{H}_{2} \mathrm{O}$ up to $10 \mathrm{Kbar}$ ", N. Jahrb. Miner. Abh., 130 (1977), pp. $169-186$.

(42) Dondi, M., Ercolani, G., Fabbri, B. y Marsigli, M.: "An approach to the chemistry of pyroxenes formed during the firing of Ca-rich silicate ceramics", Clay Miner., 33 (1998), pp. 443-452.

(43) Dondi, M., Guarini, G. y Raimondo, M.: "Trends in the formation of crystalline and amorphous phases during the firing of clay bricks", Tile \& Brick Int., 15 (1999), pp. 176-183.

(44) Velde, B. y Druc, I. C.: Archaeological ceramic materials: origin and utilization, Springer, 1999.

(44 bis) Pavia, S.: "The determination of brick provenance and technology using analytical techniques from the physical sciences", Archaeometry, 48 (2006), pp. 201-218.

(45) Schomburg, J.: "Thermal reactions of clay minerals: their significance as "archaeological thermometers" in ancient potteries", Appl. Clay Sci., 6 (1991), pp. 215-220.

(46) Mata, M. P., Peacor, D. R. y Gallart-Marti, M. D.: "Transmission electron microscopy (TEM) applied to ancient pottery", Archaeometry, 44 (2002), pp. 155-176.

(47) Bauluz, B., Mayayo, M. J., Yuste, A., Fernández-Nieto, C., Gonzáles-López, J. M.: "TEM study of mineral transformations in fired carbonate clays: relevance to brick making", Clay Miner., 39 (2004), pp. 333-344. 
(48) Duminuco, P., Riccardi, M. P., Messiga, B. y Setti, M.: "Modificazioni tessiturali e mineralogiche come indicatori della dinamica del processo di cottura di manufatti ceramici", Ceramurgia, 26, 1996, pp. 281-288.

(49) Duminuco, P., Messiga, B. y Riccardi, M. P.: "Firing process of natural clays. Some microtextures and related phase compositions", Thermochimica Acta, 321 (1998), pp. 185-190.

(50) Riccardi, M. P., Messiga, B. y Duminuco, P.: "An approach to the dynamics of clay firing", Appl. Clay Sci., 15 (1999), pp. 393-409. (51) Letsch, J. y Noll, W.: "Phasenbildung in einigen keramischen Teilsystemen bei $600-1000^{\circ} \mathrm{C}$ in Abhängigkeit von Sauerstoffugazität". Ceramic Forum Int. Ber. dtsch. keram. Ges., 60, Helf 7, 1983.

(52) Cultrone, G., Sebastian, E., Elert, K., De La Torre, M. J., Cazalla, O. y Rodriguez-Navarro, C.: "Influence of mineralogy and firing temperature on the porosity of bricks", J. Eur. Ceram. Soc. 24 (2004), pp. 547-564.

(53) Maniatis, Y., Tite, M. S.: "A scanning electron microscope examination of the bloating of fired clays", Trans. Brit. Ceram. Soc., 74 (1975), pp. 229-232.

(54) Tite, M. S. y Maniatis, Y: "Examination of ancient pottery using scanning electron microscope", Nature, 257 (1975), pp. 122-123.

(55) Hansen, W. y Kung, J. H.: "Pore structure and frost durability of clay bricks", Materials and Structures, 21 (1988), pp. $443-447$.

(56) Kühnel, R. A.: "Cause and consequence: volume changes behind building material deterioration", Materials Characterization, 53 (2004), pp. 171-180.

(57) López-Arce, P. y García-Guinea, J.: "Weathering traces in ancient bricks from historical buildings", Building and Environment, 40 (2005), pp. 929-941.

(58) Riganti, V. y Chieppi, F.: Le variazioni del microclima in Pavia e Milano come possibile indice di urbanizzazione, Atti Conv. Difesa Natura, Univ. Pavia, 1970, pp. 340-345. 